\title{
Standardization of mixed fruit cheese from Guava (Psidium guajava cv. Hisar Safeda) and Mango (Mangifera indica var. Safeda) and its quality evaluation during storage
}

\author{
Sucheta*, Rakesh Gehlot and Saleem Siddiqui \\ Centre of Food Science and Technology, CCS Haryana Agricultural University, Hisar-125004 (Haryana), INDIA \\ *Corresponding author. E-mail: suchetakkr@gmail.com
}

Received: August 31, 2016; Revised received: January 22, 2017; Accepted: April 22, 2017

\begin{abstract}
The present investigation was carried out to prepare fruit cheese, a fruit confectionery prepared by combining fruit pulp with sugar, pectin and acid from blended fruit pulp of guava (Psidium guajava) and mango (Mangifera indica). The storage studies of mixed fruit cheese packed in HDPE bags showed significant changes in chemical properties during three months storage. Total sugars, reducing sugars and browning increased significantly from 66.8 to $68.7 \%, 21.1$ to $23.4 \%$ and 0.25 to 0.37 , while carotenoids and total phenols decreased significantly from 1.2 to $0.7 \mathrm{mg} / 100 \mathrm{~g}$ and 39.1 to $35.2 \mathrm{mg} / 100 \mathrm{~g}$ in guava-mango cheese during storage. Carotenoids was maximum $(2.5 \mathrm{mg} / 100 \mathrm{~g})$ in guava-mango cheese containing highest mango pulp content, while ascorbic acid and total phenols was maximum $(13.0$ and $54.7 \mathrm{mg} / 100 \mathrm{~g})$ in cheese with highest guava pulp content. The cost of production was found minimum (Rs. 140/kg) in guava-mango cheese with 100 guava: 0 mango pulp ratio and increasing concentration of mango pulp showed a increasing trend in the cost of production of fruit cheese.
\end{abstract}

Keywords: Chemical quality, Guava, Mango, Mixed fruit cheese, Storage

\section{INTRODUCTION}

Guava (Psidium guajava L.) belongs to family Myrtaceae which contains about 100 species of tropical shrubs and small trees. Guavas are mainly cultivated in tropical and sub-tropical countries. Guava fruits are rich in dietary fibre, vitamin $\mathrm{A}$, vitamin $\mathrm{C}$, folic acid and dietary minerals mainly potassium, copper and manganese. The fruit contains about four times the amount of vitamin $\mathrm{C}$ as present in orange. Guava contains both carotenoids and polyphenols like leucocyanidin, guaijaverin, gallocatechin, the major classes of antioxidant pigments giving them relatively high antioxidant value among plant foods. Guava is also found effective against cancer, bacterial infections, inflammation and pain. Guava can be consumed fresh or can be processed into juice, nectar, pulp, jam, jelly, slices in syrup, fruit bar or dehydrated products, as well as being used as an additive to other fruit juices or pulps (Leite et al., 2006). Mango (Mangifera indica) is known as 'King of Indian Fruits' because of its high palatability, excellent taste and exemplary nutritive value (Nakesone, 1998). It is the most popular fruit and is very much relished for its succulence, exotic flavour and delicious taste. Mango pulp contains phytochemicals and nutrients. The composition of edible portion of mango fruit contains: $80 \%$ moisture, $63 \%$ calories, $0.4 \%$ protein, $0.4 \%$ fats, $16 \%$ carbohydrates, $20 \%$ vitamin-A, $3.6 \%$ thiamine, $2.5 \%$ riboflavin, $2.2 \%$ niacin, $20.20 \%$ vitamin C, $1.1 \%$ calcium and $4.0 \%$ iron (Chauchin and Cahoon, 1987; Rao and Mukherjee, 1989; Haag et al., 1990). The fruit contains antioxidants vitamin $\mathrm{A}$, vitamin $\mathrm{C}$, vitamin $\mathrm{B}_{6}$ (pyridoxine), other B-complex vitamins and essential nutrients such as potassium, copper, amino acids. Guava fruits are seasonal and highly perishable; therefore, considerable amount is lost during post-harvest. Rapid utilization of guava fruits in processed products can help to prevent economic losses to the farmers as well as Indian market. Therefore, aim of this research was to blend these fruits to produce product rich in flavor of mango and nutritional value of guava. Fruit cheese is relatively new to fruit processors. It is a fruit confectionery prepared by combining fruit pulp with sugar, pectin and acid, and cooked to achieve soluble solids of usually not less than 68 per cent (Sammy, 1994). It is usually processed like jam with the texture firm enough to be moulded and sliced (Bramwell and Badrie, 2002). Fruits like pineapple, papaya and banana, apple, pear and plum have been utilized for preparation of fruit cheese (Bramwell and Badrie, 2002; Srivastava and Kumar, 2010; Kuchi et al., 2014; and Patel et al., 2016). However, very little work has been carried out on mixed fruit cheese. This study has been carried out to prepare mixed fruit cheese from guava and mango fruits and evaluate its storage stability.

\section{MATERIALS AND METHODS}

Fruits Uniformly ripe guava fruits were procured from 
experimental farm, department of horticulture, CCSHAU, Hisar. Uniformly ripe mango fruits were procured from local market for research work.

Chemicals: Analytical grade chemicals were purchased from Titan Biotech Pvt, Ltd. Sugar and butter as ingredients were purchased from local market for preparation of mixed fruit cheese.

Packaging materials, Butter paper and HDPE bags for packaging product were obtained from local market.

Extraction of pulp from guava and mango fruits: Guava fruits were washed thoroughly with running water and cut into thin slices with stainless steel knife. The slices were then heated after addition of 25 per cent water. After cooling, slices were crushed manually through stainless steel sieve and pulp was collected in a container. Mango fruits were washed thoroughly with clean running water and peeled off. The pulp was separated from the stone with the help of a stainless steel knife and blended in a mixer to obtain fine pulp.

Standardization of mixed fruit cheese: Mixed fruit cheese was first prepared from ten blended ratios as given in table 1 . On the basis of sensory evaluation on 9-point hedonic scale by 10 semi-trained panelists, best six blended ratios were selected for further storage studies.

Preparation of mixed fruit cheese: Six different fruit cheese were prepared using guava: mango (100:0; $80: 20 ; 60: 40 ; 40: 60 ; 20: 80$ and 0:100) with $1 \mathrm{~kg}$ sugar, $80 \mathrm{~g}$ butter, $5 \mathrm{~g}$ citric acid and $5 \mathrm{~g}$ salt. The pulp was blended in given ratio, one $\mathrm{kg}$ of blended pulp was cooked with the addition of ingredients. One per cent pectin was also mixed with the cooking mass for proper setting of cheese. The mixture was cooked to obtain the desired consistency. Sodium benzoate@500 ppm was also mixed into cooked mass when it started leaving the sides of the vessel. The prepared product was then spread on butter smeared trays $(0.60 \mathrm{~cm}$ thickness) and left for 5 to 6 hours for cooling and setting. Suitable size pieces $(1-2 \mathrm{~cm})$ of cheese were cut with stainless steel knives (Srivastava and Kumar, 2010).

Packaging and storage of mixed fruit cheese: Prepared cheese was cut and then wrapped into butter paper. Three replications were made from each treat- ment. Wrapped cheese was then packed into HDPE bags subjected to storage at room temperature for 60 days. Quality evaluation was carried out at monthly interval.

Chemical analysis of mixed fruit cheese: The cheese was analyzed for total and reducing sugars according to Hulme and Narain, (1931); acidity and ascorbic acid according to AOAC, (1990); carotenoids according to Rodriguez-Amaya (1999), pectin, total phenols and non-enzymatic browning according to Ranganna (2003).

Microbial quality of mixed fruit cheese: Microbial quality was determined as total plate count (TPC). The TPC was determined by surface spreading $10^{-2}$ dilution of prepared sample $\left(1 \mathrm{~g}\right.$ in $\left.9 \mathrm{ml} \mathrm{H}_{2} \mathrm{O}\right)$ on plate count agar (PCA) and incubated at $37{ }^{\circ} \mathrm{C}$ for $24-48 \mathrm{~h}$. The colonies were counted and results were expressed as $\log \mathrm{CFU} / \mathrm{g}$.

Statistical analysis: The results obtained were subjected to analysis of variance (ANOVA) techniques and analyzed according to completely randomized design. The critical difference value at 5 per cent level was used for making comparison among different treatments during three months storage period.

\section{RESULTS AND DISCUSSION}

Physico-chemical characteristics of fresh fruits: Average fruit weight (126 and $616 \mathrm{~g}$ ), pulp weight (838 and $695 \mathrm{~g} / \mathrm{kg}$ fruit), yield of pulp (83.8 and 69.5 $\%)$, total soluble solids $(9.3$ and $17.7 \%)$, total sugars (7.10 and $14.51 \%)$, reducing sugars (3.60 and 6.08 $\%)$, pectin $(0.94$ and $0.54 \%)$ and total phenols (110 and $53.1 \mathrm{mg} / 100 \mathrm{~g}$ ) were recorded for guava and mango fruits, respectively. In mango fruit, carotenoids were recorded as $3.54 \mathrm{mg} / 100 \mathrm{~g}$. Similar results were reported by Bhuyan and Kobra (2007) in mango, Nag et al., (2011) and Anupa et al., in guava 012) in guava.

Standardization of mixed fruit cheese: On the basis of highest scores given by panelists for colour and appearance, flavor, mouthfeel, texture and overall acceptability, six treatments were selected for storage study as shown in table 2 .

Table 1. Guava-Mango blended pulp ratios for standardization of mixed fruit cheese.

\begin{tabular}{|c|c|c|c|c|c|c|c|}
\hline $\begin{array}{l}\text { Treat- } \\
\text { ment No. }\end{array}$ & $\begin{array}{c}\text { Guava pulp } \\
(\%)\end{array}$ & $\begin{array}{c}\text { Mango pulp } \\
(\%)\end{array}$ & $\begin{array}{c}\text { Sugar (g/ } \\
\text { kg of pulp) }\end{array}$ & $\begin{array}{c}\text { Butter (g/ } \\
\text { kg of pulp) }\end{array}$ & $\begin{array}{c}\text { Citric acid(g/ } \\
\text { kg of pulp) }\end{array}$ & $\begin{array}{c}\text { Salt (g/kg } \\
\text { of pulp) }\end{array}$ & $\begin{array}{l}\text { Overall acceptabil- } \\
\text { ity (score out of 9) }\end{array}$ \\
\hline 1 & 100 & 0 & 1000 & 80 & 5 & 5 & 8.2 \\
\hline 2 & 80 & 20 & 1000 & 80 & 5 & 5 & 8.4 \\
\hline 3 & 75 & 25 & 1000 & 80 & 5 & 5 & 8.0 \\
\hline 4 & 60 & 40 & 1000 & 80 & 5 & 5 & 8.0 \\
\hline 5 & 50 & 50 & 1000 & 80 & 5 & 5 & 7.9 \\
\hline 6 & 50 & 50 & 750 & 80 & 5 & 5 & 7.8 \\
\hline 7 & 40 & 60 & 1000 & 80 & 5 & 5 & 8.1 \\
\hline 8 & 25 & 75 & 1000 & 80 & 5 & 5 & 8.0 \\
\hline 9 & 20 & 80 & 1000 & 80 & 5 & 5 & 8.2 \\
\hline 10 & 0 & 100 & 1000 & 80 & 5 & 5 & 8.3 \\
\hline
\end{tabular}

*Overall acceptability is mean of color and appearance, taste, flavor, mouthfeel and texture scored by panel of ten judges 
Sucheta et al. / J. Appl. \& Nat. Sci. 9 (2): 791 - 795 (2017)

Table 2. Chemical quality evaluation of fresh mixed fruit cheese.

\begin{tabular}{|c|c|c|c|c|c|c|c|}
\hline $\begin{array}{l}\text { Treatment No. } \\
\text { (G:M) }\end{array}$ & $\begin{array}{c}\text { Cost of } \\
\text { production } \\
(\mathrm{Rs} / \mathrm{Kg})\end{array}$ & $\begin{array}{c}\text { Total } \\
\text { sugars } \\
(\%) \\
\end{array}$ & $\begin{array}{c}\text { Reducing } \\
\text { Sugars } \\
(\%) \\
\end{array}$ & $\begin{array}{c}\text { Ascorbic } \\
\text { acid } \\
(\mathrm{mg} / \mathbf{1 0 0 g})\end{array}$ & $\begin{array}{c}\text { Carotenoids } \\
(\mathrm{mg} / 100 \mathrm{~g})\end{array}$ & $\begin{array}{c}\text { Total } \\
\text { phenols } \\
(\mathrm{mg} / \mathbf{1 0 0 g})\end{array}$ & $\begin{array}{c}\text { Browning } \\
\text { (O.D. at } \\
440 \eta \mathrm{m}) \\
\end{array}$ \\
\hline $1(100: 0)$ & 140 & 64.6 & 17.9 & 13.0 & N.D & 54.7 & 0.38 \\
\hline $2(80: 20)$ & 142 & 65.9 & 19.4 & 9.0 & 0.5 & 47.4 & 0.31 \\
\hline $3(60: 40)$ & 145 & 66.7 & 20.1 & 6.4 & 0.9 & 40.6 & 0.27 \\
\hline $4(40: 60)$ & 146 & 67.0 & 21.6 & 5.2 & 1.4 & 35.6 & 0.22 \\
\hline $5(20: 80)$ & 146 & 67.9 & 23.2 & 4.8 & 1.8 & 30.2 & 0.19 \\
\hline $6(0: 100)$ & 148 & 68.9 & 24.1 & 2.5 & 2.5 & 26.5 & 0.15 \\
\hline Mean & - & 66.8 & 21.1 & 6.8 & 1.2 & 39.1 & 0.25 \\
\hline S.E. \pm & - & 0.25 & 0.20 & 0.06 & 0.04 & 0.06 & 0.01 \\
\hline C.D at $5 \%(n=3)$ & - & 0.78 & 0.63 & 0.21 & 0.13 & 0.19 & 0.04 \\
\hline
\end{tabular}

*observations were recorded in triplicates

Table 3. Changes in chemical composition and microbial quality after 90 days storage.

\begin{tabular}{|c|c|c|c|c|c|c|c|}
\hline $\begin{array}{l}\text { Treatment } \\
\text { (G:M) }\end{array}$ & $\begin{array}{l}\text { Total } \\
\text { sugars } \\
(\%) \\
\end{array}$ & $\begin{array}{l}\text { Reducing } \\
\text { Sugars } \\
(\%) \\
\end{array}$ & $\begin{array}{l}\text { Ascorbic acid } \\
\text { (mg/100g) }\end{array}$ & $\begin{array}{l}\text { Carotenoids } \\
\text { (mg/100g) }\end{array}$ & $\begin{array}{l}\text { Total } \\
\text { phenols } \\
(\mathrm{mg} / 100 \mathrm{~g}) \\
\end{array}$ & $\begin{array}{l}\text { Browning } \\
\text { (O.D. at } 440 \\
\eta \mathbf{m})\end{array}$ & $\begin{array}{l}\text { SPC } \\
\text { (CFU/g) }\end{array}$ \\
\hline $1(100: 0)$ & 66.6 & 20.5 & 11.5 & N.D. & 51.4 & 0.54 & 6.2 \\
\hline $2(80: 20)$ & 67.4 & 21.6 & 7.6 & 0.2 & 42.7 & 0.46 & 5.6 \\
\hline $3(60: 40)$ & 68.6 & 22.7 & 4.9 & 0.6 & 36.4 & 0.42 & 5.2 \\
\hline $4(40: 60)$ & 68.9 & 23.7 & 3.9 & 0.9 & 32.0 & 0.32 & 4.9 \\
\hline $5(20: 80)$ & 70.3 & 24.8 & 3.0 & 1.1 & 22.6 & 0.29 & 4.4 \\
\hline $6(0: 100)$ & 70.6 & 27.4 & 0.4 & 1.5 & 26.1 & 0.22 & 3.9 \\
\hline Mean & 68.7 & 23.4 & 5.2 & 0.7 & 35.2 & 0.37 & 5.0 \\
\hline S.E. \pm & 0.21 & 0.23 & 0.06 & 0.01 & 0.08 & 0.01 & 0.09 \\
\hline C.D at $5 \%(n=3)$ & 0.68 & 0.72 & 0.20 & 0.04 & 0.25 & 0.03 & 0.30 \\
\hline
\end{tabular}

*observations were recorded in triplicates

Cost of production of mixed fruit cheese: The cost of production of six different variants of mixed fruit cheese varied from $140 \mathrm{Rs} / \mathrm{Kg}$ of pulp to $148 \mathrm{Rs} / \mathrm{Kg}$ of pulp. It was found maximum in blended pulp ratio with maximum mango pulp content i.e. $148 \mathrm{Rs} / \mathrm{Kg}$ and minimum in ratio with lowest guava pulp content i.e. 140 $\mathrm{Rs} / \mathrm{Kg}$.

Chemical composition of fresh mixed fruit cheese: Total sugars content of mixed fruit cheese ranged from 64.6 to $68.9 \%$. There was significant difference in total sugars content of mixed fruit cheese among different blended ratios, maximum total sugars (per cent) was found in $0 \mathrm{G}$ : $100 \mathrm{M}$ blended pulp ratio. Reducing sugars of mixed fruit cheese was found maximum $(24.1 \%)$ in guava: mango $(0: 100)$ and ranged from 17.9 to $24.1 \%$ among all treatments. There was significant difference in ascorbic acid content among different treatments and it ranged from 13.0 to $2.5 \mathrm{mg} / 100 \mathrm{~g}$ of product. Pure guava cheese contained carotenoids not in detectable amount and it increased with an increase in mango pulp content in fruit cheese. Maximum carotenoids were found in pure mango fruit cheese as $2.5 \mathrm{mg} / 100 \mathrm{~g}$ of product. Total phenols and browning decreased with increase in mango pulp content in mixed fruit cheese. $54.7 \mathrm{mg} / 100 \mathrm{~g}$ total phenols was found in treatment guava: mango (100: 0). Similarly maximum browning (0.38) as O.D. at $440 \mathrm{~nm}$ was found in guava: mango (100: 0) and minimum (0.15) in guava: mango (0: 100) fruit cheese.

Changes in chemical composition and microbial quality of mixed fruit cheese during storage: There was a gradual and significant increase in total sugars of guava-mango cheese and toffee with the advancement of storage period. The increase in level of sugars may be attributed to loss of moisture from the blended products. The increase in total sugars could be due to conversion of insoluble polysaccharides and other carbohydrate polymers to soluble sugars as reported by (Kuchi et al., 2014). Mehto and Mehto (2017) conducted studies on guava cheese and they reported significant increase in total sugars during storage which might be due to breakdown of polysaccharides and insoluble carbohydrate polymers into simple sugars. The increase in reducing sugars can be attributed to the conversion of sugars to reducing sugars by hydrolysis. Similar results were reported by Choudhary et al. (2008) in guava nectar and Mahajan et al. (2011) in pineapple bar. Parab et al. (2014) reported significant increase in reducing sugars in fortified mango bar during 90 days storage. The ascorbic acid content of blended products decreased significantly in blended cheese and toffee during storage. Similar results were observed by Mehto and Mehto (2017) in guava cheese. Total carotenoids decreased significantly in guavamango cheese and toffee during three months storage period. Similar decrease in total carotenoids was reported by Castro-Lopez et al. (2016) in fruit beverages during storage. This might be due to susceptibility of pigments to oxidation. The decrease in polyphenols could mainly be resulted from oxidation of these com- 
pounds and polymerization with proteins (Liu et al., 2014). Similar results were reported by Saci et al. (2015) in fruit based beverages. Browning of guavamango cheese and toffee increased significantly during three months storage. Similar results were reported by Parab et al. (2014) in mango bar. Deepika et al. (2016) reported that non-enzymatic browning in fruit bars from aonla increased during storage and this may be due to formation of furfural and hydroxyl furfural by aerobic and anaerobic degradation of ascorbic acid and also due to reaction between ascorbic acid, sugars and organic acid. The results also indicated that microbial count increased during storage, this may be due to increased water availability due to increased moisture on surface of cheese during storage. Blending of fruits resulted in increased carotenoids (contributed by mango), increased ascorbic acid and phenolic content (as contributed by guava), thus making blended fruit cheese nutritious and more shelf stable as compared to the cheese made from individual fruits.

\section{Conclusion}

Guava and mango fruits can be blended in appropriate ratio to produce fruit cheese with improved chemical and microbiological quality. Increase in mango content showed decreased ascorbic acid (13.0-2.5 mg/100g) and phenolic content (54.7 to $26.5 \mathrm{mg} / 100 \mathrm{~g}$ ) but increased carotenoid content $(0.5-2.5 \mathrm{mg} / 100 \mathrm{~g})$ of fruit cheese. The stored cheese showed significant increase in total sugars, reducing sugars and non-enzymatic browning, whereas decrease in carotenoids, total phenols and ascorbic acid. However, blended cheese prepared can be stored at room temperature for three months without much loss in eating without much loss in nutritional quality like guava and mango, different fruits can be blended to produce products with improved quality and acceptability.

\section{REFERENCES}

AOAC (1990). "Official Methods of Analysis". Association of Official Analytical Chemists. Washington, D.C. $15^{\text {th }}$ edition.

Anupa, T., Jaganath, S., Girisha, R. and Mallikarjuna gowda, A. P. (2012). Studies on qualitative charcterisitcs in different genotypes of Apple Colour guava. Int. J. Agric. Env. Biotech., 5(2): 109-112

Bhuyan, M. A. J. and Kobra, K. (2007). Fruit characteristics of some uncommon mango varieties grown under Joydebpur condition. Bangladesh J. Agric. Res., 32(3): 493-500

Bramwell, M. G. and Badrie, N. (2002). Processing and quality evaluation of banana cheese. J. Food Sci. Technol., 39(5): 537-541

Castro-Lopez, C., Sanchez-Alejo, E. J., Saucedo-Pompa, S., Rojas, R., Aranda-Ruiz. J. and Martinez-Avila, G. C. G (2016). Fluctutations in phenolic content, ascorbic acid and total Carotenoids and antioxidant activity of fruit beverages during storage. Heliyon, 2: 1-16

Chauchin, K. S. and Cahoon, G. A. (1987). Mineral status of mango cultivars in Rajasthan. Haryana J. hortic. Sci., 16(1-2): 20-24

Choudhary, M. L., Dikshit, S. N., Shukla, N. and Saxena, R. R. (2008). Evaluation of guava (Psidium guajava L.) varieties and standardization of recipe for nectar preparation. Journal of Horticultural Sciences, 3(2):161-163

Deepika Panja, P., Marak, D. S. and Thakur, P. K. (2016). Effect of packaging on quality of enriched fruit bars from aonla (Emblica Officinalis G) during storage. International Journal of Agriculture, Environment and Biotechnology, 9(3): 411-419

Haag, H. P., Souza, M. E. P., Carmello, G. A. C. and Decheu, A. R. (1990). Removal of the macro and micro-nutrients by fruits of four mango (Mangifera indica L.) cultivars. Anais da Escola Superior de Agriculture 'Luiz de Queiroz', 47(2): 459-477

Hulme, A. C. and Narain, R. (1931). The ferricyanide method for determination of reducing sugars. A modification of Hagedom-Jenseen-Hanes technique. Biochem. J., 25: 1051-1061

Kuchi, V. S., Gupta, R., Gupta, R. and Tamang, S. (2014). Standardization of recipe for preparation of guava jelly bar. Journal of Crop and Weed., 10(2): 77-81

Leite, K. M. S. C., Tadiotti, A. C., Baldochi, D., Oliveira, O. M. M. F. (2006). Partial purification, heat stability and kinetic characterization of the pectin methylesterase from Brazilian guava Plauma cultivars. Food Chem., 94: 565-572

Liu, F., Wang, Y., Li, R., Bi, X. and Liao, X. (2014). Effects of high hydrostatic pressure and high temperature short time on antioxidant activity, antioxidant compounds and color of mango nectars. Innovative Food Science and Emerging Technologies, 21: 35-43

Mahajan, R.N., Taur, A.T., Sawate, A. R. and Kshrisagar, R. B. (2011). Studies on preparation of low calorie high protein pineapple bar. Beverage and Food World, $58-62$

Mehto, A. and Mehto, P. K. (2017). Guava cheese preparation to reduce the perishable loss of fruits and influence of the chemical composition during storage of cheese. International Journal of Food Science and Nutrition, 2 (1): 1-3

Nag, A. R., Chatterjee, D. D., Ray, T., Hossain, A. M. M. Z. and Haque, M. A. (2011). Study on chemical changes of different guava varieties during different ripening stage. Bangladesh Res. Pub. J., 6(2): 217-224

Nakesone, H. Y. (1998). Tropical fruits. University of Hawai at Manoa. Honolulu, HI, USA. Pp. 208-238

Parab, A. Y., Relekar, P. P. and Pujari, K. H. (2014). Studies on preparation of mango (Mangifera indica L.) bar from frozen Alphonso mango pulp. The Asian Journal of Horticulture., 9(1): 243-247

Patel, P., Ellis, K., Sunkara, R., Shackelford, L., Ogutu, S., Walker, L. T., Herring, J. and Verghese, M. (2016). Development of a functional food product using guavas. Food and Nutrition Sciences, 7: 927-937

Ranganna, S. (2003). "Handbook of Analysis and Quality Control for Fruit and Vegetable Products". Tata McGraw Hills Publishing Co. Ltd., New Delhi.

Rao, D. P. and Mukherjee, S. K. (1989). Nutrient status in leaf and soil of some cultivars of mango in relation to yield. Acta Hort., 23(1): 286-295

Rodriguez-Amaya, D. B. (1999). A Guide to Carotenoids 
Sucheta et al. / J. Appl. \& Nat. Sci. 9 (2): 791 - 795 (2017)

Analysis in Foods. ILSI Press, Washington Pp. 63

Saci, F., Meziant, L. and Louaileche, H. (2015). Effect of storage time and temperature on the health promoting substances and antioxidant activity of two commercial fruit beverages. International Journal of Bioinformatics and Biomedical Engineering, 1(2): 118-122

Sammy, L. (1994). Processing of West Indian Cherry, guava, tamarind, plum and dunks. Inter-American Institute for Co-operation of Agriculture Paper presented at InterAmerican Institute. Third Regional Workshop. May 1620, 1994, St. Georges, Grenada, Pp. 140-142

Srivastava, R. P. and Kumar, S. (2010). Fruit and vegetable preservation. International Book Distributing co., Ltd, Lucknow 